\title{
THE LEGAL FRAMEWORK FOR THE IMPLEMENTATION OF CURRENCY REGULATION IN SOME FOREIGN COUNTRIES AND IN UKRAINE
}

\author{
Bohdan Stetsiuk ${ }^{1}$ \\ Institute of Jurisprudence and Psychology, Lviv Polytechnic National University, Ukraine \\ Oleksandr Slyvka ${ }^{2}$ \\ Uzhhorod National University, Ukraine \\ Oleksandr Bashynskyi ${ }^{3}$ \\ National Academy of Internal Affairs of Ukraine, Ukraine
}

\begin{abstract}
The purpose of the article is to conduct a comparative legal study of laws and regulations that determine the legal framework for the implementation of currency regulation in some foreign countries and in Ukraine and to define ways for improving domestic legislation in this area on this basis. The subject of the study is the experience of currency regulation in some European countries, USA, China, and Ukraine. Methodology. The research is based on a comparison of foreign exchange regulation in Ukraine and abroad. Based on the analysis of peculiarities of the state regulation of currency circulation in Great Britain, Germany, France, Poland, the USA, China, and in some other countries, the advantages and disadvantages of different regimes of state control over currency circulation are determined: from the regime of the floating rate to the rigorous state control. On the basis of the comparative legal study of certain provisions of the administrative legislation of Ukraine, the possibilities and limits of the application of positive foreign experience in this area are determined. The results of the study showed that in order to implement foreign exchange management experience, it is necessary to postpone the final transition to establishing a floating rate regime, reinforcing state interference. At the same time, it is necessary to strengthen currency control not only over the implementation of foreign exchange operations but also over the activities of entities that determine the state policy in the field of currency regulation, as well as directly implement the relevant activities using the instruments determined by provisions of the current legislation. Practical implications. The positive experience of the formation of the foreign exchange market in foreign countries shows that the gradual transition from a fixed to a floating exchange rate is the beginning of a natural market exchange rate formation, equalization of the balance of payments, and the gradual liberation of the national economy from the pressure of administrative and corruption restrictions. Value/originality. Conducting a comparative analysis of foreign exchange regulation in foreign countries is the basis for developing the most promising directions for the development of domestic legislation in this area.
\end{abstract}

Key words: foreign experience, currency regulation, currency exchange rate, currency control, EU countries.

JEL Classification: G15, G17, G18

\section{The relevance of the problem}

The current state of development of the world economy is characterized as extremely risky. The study of causes of disturbances of balance and economic stability in the world makes it possible to conclude on the significant role of monetary policy in strengthening crisis phenomena. The key issue for the country's investment attractiveness is the ability of the rules of currency regulation to be as flexible as possible with respect to foreign investors (Savka, Miedieliaieva).

Most countries of the world have rules of currency regulation or currency control in one form or another. The existence of such rules of currency regulation has always been noted as an important component of state

\footnotetext{
Corresponding author:

${ }^{1}$ Department of History of State and Law, Institute of Jurisprudence and Psychology, Lviv Polytechnic National University.

E-mail: sbr@gmail.com

${ }^{2}$ Department of Administrative, Financial and Information Law, Uzhhorod National University.

E-mail: slivkaoo@gmail.com

${ }^{3}$ Department of History of State and Law, National Academy of Internal Affairs of Ukraine.

E-mail: bashoa@ukr.net
} 
regulation, which affects all participants in foreign transactions in the country. The stability of the country's economic development, high rates of economic growth are largely determined by the state of national currency relations, which, in turn, is determined by the monetary policy pursued in the country. Foreign exchange policy as one of the main forms of regulation of foreign economic relations becomes of paramount importance in the practical realization of state influence on the course of all economic processes in order to implement the strategy of economic development and the development of an effectively functioning market mechanism in Ukraine.

That is why the study of foreign experience in the implementation of monetary policy becomes relevant and important since both the development of market relations and the expansion of foreign economic relations and general ensuring the economic security of the state and economic development depends on its effectiveness (Sorokivska, 2013), which determined the relevance of the selected theme.

A significant contribution to the study of the problem of choosing the optimal foreign exchange policy for countries with a transformational economy has been made by foreign and domestic scientists: J. Fraenkel, O. Bereslavska, Ya. Belinska, O.I. But, A. Halchynskyi, O. Dziubliuk, F. Zhuravka, Zh.V. Zavalna, V. Kovalenko, B. Lapchuk, S. Makukha, S.Ya. Morynets, O. Romanyshyn.

\section{The purpose of the article}

The purpose of the article is to conduct a comparative legal study of laws and regulations that determine the legal framework for the implementation of currency regulation in some foreign countries and in Ukraine and to determine on this basis ways for improving domestic legislation in this area.

Many scholars and researchers are of the opinion that Ukrainian currency control rules are restrictive and close to very strict ones. Although the National Bank of Ukraine initiated a significant number of changes to existing exchange control rules by proposing amendments to existing legislation or by introducing its own explanatory rules, such changes are mostly partial and very slow. Consequently, the Ukrainian currency control rules remain backward and not renewed for a long period of time (Savka, Miedieliaieva).

In terms of the globalization of all forms of international economic activity, the monetary policy of any country is one of the most important elements of its economic strategy since the national currency systems link the economies of individual countries into a single world economic complex (Motorniuk, Kalynovska, 2010).

Globalization of society not only contributes to the positive interpenetration of cultures, the strengthening of the country's potential by joining the world's best intellectual assets, the study of historical experience in solving socially important issues (Sevruk, Pavlenko, 2015).

Thus, an increase in the volume of foreign exchange operations in Ukraine, effective organization of foreign economic activity of economic entities, development of the national currency system and a full-fledged currency market exacerbate the problem of the dialectic combination of market and administrative methods of economic management and require strengthening of the state regulatory influence on the activities of subjects of currency relations (Melykh, 2012).

In developed countries with a socially-oriented market economy, the entrepreneurial sphere of activity is its leading sector. It is because of it that a new layer of owners is formed - the middle class, which is the social base of the existing socio-economic system.

\section{Presentation of the main research material}

Ukraine at the present stage of its development is on the path of significant transformations: the structure of economic relations is changing, new subjects of property and political activity are forming, the basic values are transforming, core values life, the way of life, and traditions are changing (Sevruk, 2017).

The transition from the planned and administrative management of the economy to market relations required from our state to create appropriate market institutions. Realizing the importance of the formation of the non-state sector as one of the components of a market economy, Ukraine, from the first years of independence, began to create legal conditions for the development of entrepreneurship (Kamlyk, 2005).

Therefore, the monetary regulation of any state is realized through the mechanism of currency restrictions and currency control. When conducting currency regulation, the state regulates the system of international settlements performed by participants of foreign economic activity, and establishes (Platonova, 1996):

- The scope and procedure for conducting foreign exchange transactions;

- Procedure for the formation and use of the currency reserve of the country;

- Procedure for the formation and use of currency funds of economic entities;

- The scope and procedure for the implementation of currency control.

Foreign exchange restrictions as a system of state measures (administrative, legislative, economic, and organizational) for establishing a procedure for conducting operations with currency values usually involve the regulation of international payments and transfers of capital, repatriation of export earnings, profits, notes and securities, the prohibition of free sale of foreign currencies (Krokhina, 2015). 
In the passive balance of payments, such measures are used to restrict the export and "escape" of capital, stimulating the flow of capital in order to maintain the exchange rate:

- Limiting the export of national and foreign currency, gold, securities, loans;

- Control over the activities of the credit and stock markets, which means that transactions are carried out only with the permission of the Ministry of Finance and when providing information on the size of loans and direct investment abroad, the attraction of foreign loans provided the prior approval of the currency control authorities (in particular, for the issuance of bonds loans) so that they do not affect the national currency market, the market for loan capital, and the growth of money supply in circulation (Krokhina, 2015);

- Restrictions on the participation of national banks in the provision of international loans in foreign currency; - Forced redemption of foreign securities owned by residents and their sale for currency (Germany resorted to this event before the Second World War and Great Britain - in the post-war period);

- Complete or partial termination of foreign debt repayment or payment in its national currency without the right to transfer abroad.

With an active balance of payments in order to curb both the inflow of capital to the country and to increase the national currency, the following forms of currency and credit restrictions on international financial transactions are applied:

- Depositing in a central bank's non-interest account of new international obligations of banks (in Germany in 1978 , the minimum reserves of credit institutions that they are obliged to keep in the central bank were raised to $100 \%$ increase in foreign liabilities of banks; in Japan, this rule was raised in March 1978 from 50\% to 100\% in order to suspend the flow of dollars into the country; in December 1978, it was reduced to $50 \%$ after the announcement of the US dollar support program; since February 1979 it was 0.25\%) (Krokhina, 2015);

- Prohibition on non-residents' investments and sale of national securities to foreigners (in Switzerland in 1972-1974, partly, and from February 1978 to the end of 1979 , the sale of short-term Swiss securities to nonresidents was almost completely prohibited; in January 1978 , sales of national securities for a term of two to four years to foreigners were prohibited in Germany; in Japan, the ban on short-term bonds purchases by nonresidents in yen was temporarily imposed in March 1978);

- Mandatory currency exchange of national currency loans at the national central bank;

- Prohibition on payment of interest on term deposits of foreigners in the national currency (a similar prohibition was in force in Switzerland from November 1974 to February 1980 for the purpose of redistributing capital from the country to the euro-Swiss franc market and reducing the exchange rate of the national currency) (Krokhina, 2015);

- The introduction of a negative interest rate on deposits of non-residents in the national currency (from 12 to $40 \%$ per annum). At the same time, the interest is paid either by the bank's depositor, or by the bank itself that is interested in attracting foreign currency deposits to the relevant government institution (this measure was applied at different times by Belgium, the Netherlands, Germany, Switzerland (1972-1979) in order to curb the inflow of capital; for example, in Switzerland in 1978, the rate of "negative" interest was $10 \%$ in the quarter for contributions from non-residents in Swiss francs to more than 5 million francs) (Krokhina, 2015);

- Restrictions on the import of currency into a country (this measure was introduced in Switzerland in 19761977; then the Banking Act of 1979 prohibited banks from storing banknotes in Swiss francs in safes leased by foreigners, keeping checks for large amounts issued on their behalf by order foreign clients);

- Restrictions on forward sales of the national currency to foreigners (in Switzerland, these restrictions were practiced between November 1974 and March 1980, then they were mitigated: based on the sale of francs for up to ten days the limit was increased from 20 to $40 \%$ of the amount of the transaction as of 31 October 1974, for operations for a longer term - from 50 to $80 \%$ );

- The scheme of compulsory deposits (this measure was used in Germany from March 1972 to September 1974; firms that are actively resorting by Eurocredits, for which rates were lower than in the country, were obliged to place a part of the attracted capital at a non-interest account in the German Federal Bank) (Krokhina, 2015).

Conducted analysis of the main approaches to the definition of mechanisms for the unshadowing of the Ukrainian economy provides grounds for arguing that the main mechanisms, according to scientists, are economic (improving the tax system, reforming the national financial control system, stimulating investment processes, creating favourable conditions for business development, fighting corruption, etc.). It is necessary to agree with the opinion of S.O. Pavlenko that corrupted ties, which are closely regulated in the legislative, executive, and judicial authorities, lead to the establishment of their dependence on criminal structures, which ensures the adoption of necessary decisions for them, in violation of current legislation or existing social norms (Pavlenko, 2016).

In our view, for the national economy, integrated into the world, the fuller implementation of the liberal idea of foreign exchange control is of great practical importance. At the same time, we cannot neglect the stage of transition from less liberal currency control to more liberal, so as not to suffer certain losses. As rapid liberalization of currency control, so unjustified tight measures can lead to negative social and economic 
consequences. For a deeper understanding of the essence of relations in the field of currency control in order to improve the national currency system, it is expedient to study the practice of currency control in developed European countries (Dzhavaha, 2014).

Let us also dwell on the system of currency control in Germany. Legally, the system of currency control in this country has existed since 1949 when the Law "On Foreign Exchange Turnover and Control of Goods" was adopted (Foreign Exchange Law). The law contained a prohibition (with the obligation to request permission) on transactions with property between citizens and foreigners, a ban on the movement of currency, provisions on currency control. And by this time, the Law is the basic document defining currency relations in the country. In our time, currency control in Germany is carried out on the basis of the Foreign Exchange Law of 1949 (Yalta Interbank Conference: more questions than answers, 2004).

One of the main principles of the economy in Germany is the free movement of capital. However, despite the capital movement liberalization, there is a strict control in the form of accounting of capitals that cross the state border. Mostly, banks, as well as other lending organizations, which transfer collected and aggregated information to central banks of lands or directly to the central bank of the country, deal with this issue. Such a collection and analysis of data on the movement of capital allows developing, if necessary, specific measures for the regulation of the currency market, and is also used in compiling the balance of payments of the Federal Republic of Germany by a special unit of the Deutsche Bundesbank (Federal Bank) (Kizenkov, 1997).

As a result of the liberalization of currency legislation in the FRG, the issue of organizing effective counteraction to the use of financial systems for the purpose of laundering of the proceeds of crime has become particularly relevant. Therefore, the FRG is actively involved in expanding international cooperation in the fight against money laundering, while taking appropriate measures at the national level.

Thus, in the system of currency control in Germany, there are relevant legislative acts, currency transactions related to the movement of capital are monitored, and the fight against the legalization of criminal proceeds is carried out. The currency control authorities are the German Federal Bank, the central banks of land, commercial banks, and other lending institutions (Dzhavaha, 2014).

In 1989, in Italy, the Decree on Currency Regulation was adopted, which allowed carrying out any currency activity that did not contradict the law. Since 1989, the Italian Foreign Exchange Office serves the circulation of all funds in foreign currency. Together with the Bank of Italy, this body also manages official currency reserves. Coordination of activities of these two institutions is ensured by the fact that the central bank manager is simultaneously the head of the Italian Foreign Exchange Office. Control over export-import foreign exchange operations is also carried out by the customs services, which submit their received information about illegal actions in the financial sphere to the Italian Foreign Exchange Office and the Guardia di Finanza.

In 1995, the Italian Foreign Exchange Office created a special department to combat the prevention of the use of financial institutions to launder criminal proceeds (Kolesnikov, Shmyreva, Klimov, 1999).

It is also worth studying features of the currency control system in Great Britain. The foundations of the current system of currency and export control of Great Britain were laid in the pre-war period - in 1939 when the Prescriptions on Defence (Finance) and the Law "On Import, Export and Customs Authorities" were adopted. Since 1947 the Law "On Currency Control” has entered into force, as well as more than 40 statutory documents, including orders, rules, and directives issued by the Treasury and the Bank of England (Platonova, 1996). Among the modern statutory instruments regulating foreign exchange controls, the Law "On Import and Export" of 1990, the Order "On Export Control of Goods" of 1979 should be noted (Khamaganova, 2001).

The Law "On Currency Control" provides authority and imposes obligations and restrictions on the circulation of currency values. Currency control authorities include the Treasury, the Bank of England and authorized banks with exchange permit, as well as customs and excise authorities. British Treasury is the main authority of the currency control. However, it delegated most of its powers to the Bank of England, which directly exercises currency control. The Bank of England manages its affiliates and authorized representative offices in most commercial banks (both domestic and foreign) located in Great Britain and executing a wide range of transactions with its permission. The customs and excise authorities control the movement of capital and currency across the border (Shmyreva, 1999).

Thus, in Great Britain, individual elements of the currency control system continue to be applied. Yes, there are restrictions on the circulation of currency values, control over foreign currency investment, the fight against the legalization of proceeds of crime, which involves the Joint Working Group and the National Bank of the United Kingdom for Financial Investigations, are being actively pursued.

In Poland, with the commencement of the reform process, a fixed exchange rate was introduced - first to the US dollar, and then to the "basket" of the top five currencies, to curb inflation. In May 1995, the regime for fixing the exchange rate was changed to the "currency corridor", the limits of which gradually expanded from $\pm 7 \%$ to $\pm 15 \%$. Since April 2000 , as a result of the introduction of free floatation of the exchange rate on the 
Polish zloty course, market factors begin to affect. In the mid-90s of the XX century, the National Bank of Poland actively used exchange rate policy to combat inflation. The strengthening of the zloty's exchange rate in 20002001 occurred as a result of the large privatization proceeds and consistent restricting monetary policy of the Polish government, as well as the inflow of foreign capital (Honcharuk, Matsko, Shparhalo, 2010).

On July 27, 2002, a new law "On Foreign Currency" was issued in Poland, which regulates the execution of foreign exchange transactions. This law abolished all restrictions on the movement of funds between Poland and the EU countries. At the same time, the law provides for some restrictions regarding the movement of funds from non-EU countries. Currency restrictions can be removed by obtaining currency permits that are of two types: general and private. The general currency permits are issued by the Ministry of Finance, and private ones - by the National Bank of Poland. The main measure of currency regulation was the transition to a flexible exchange rate and the introduction of the "free-swimming" regime in 2000. Thus, the government and the National Bank of Poland were able to solve the problem of the impossibility of combining three goals, namely: stability of the exchange rate, capital mobility, and monetary autonomy (Zhuravka, 2008).

On the basis of the above analysis, one can conclude that the common for most developed European countries is the fact that in the post-Second World War period, currency control was rather rigorous. With the improvement of their currency and financial status, such countries have gradually liberalized currency control.

In intergovernmental relations, currency restrictions can be used to establish a currency blockade - an economic sanction in the form of one-sided currency restrictions of one country or group of countries in relation to another state, which impede the use of its currency values in order to force it to comply with certain requirements and are aimed at undermining its currency-economic situation.

The application of such measures allows freezing the foreign currency values stored in the accounts with foreign banks of the state, against which the currency blockade is directed, to discriminate it as a trading partner. For example, in the period of the AmericanIranian conflict in November 1979, the USA blocked Iranian bank accounts (12 billion USD) and cancelled some loans, demanding the release of American hostages, and ultimately in order to undermine the country's economy, which began to pursue antiAmerican policies. During the Falklands Conflict in 1982, Britain blocked Argentina's currency assets, which then dropped off its example. In January 1986, the USA announced the currency blockade of Libya, freezing its currency assets in American banks in order to force the country to abandon its independent foreign policy. In 2003, the USA froze Iraq's foreign currency accounts.
International sanctions against Iraq were abolished in the spring of 2003 after the US and British military operations in that country ended (Krokhina, 2015).

The currency policy is closely interrelated with the transformational and monetary processes taking place in the economies of different countries. Thus, most Eastern European and CIS countries were undergoing stagflation at the stage of transformations, so central banks were forced to introduce a fixed exchange rate regime with the purpose of curbing inflation. Further gradual recovery and the development of financial and money markets contribute to the liberalization of the exchange rate and the operation of the foreign exchange market as a complete monetary regulation tool (Honcharuk, Matsko, Shparhalo, 2010).

In general, it should be noted that for most countries of the world (which was and is), a widespread use of various currency restrictions and even a state monopoly in the currency sphere are peculiar.

World experience shows that the choice of the exchange rate regime is an equally important element in the realization of foreign exchange policy. There are many good examples of using floating, fixed modes or their combinations. Recently, however, most countries prefer the regime of floating exchange rates. This is determined by the fact that, in the long run, there is no alternative to the floating regime, because long-term stability at a fixed rate cannot be achieved. However, in the short run, currency policy is obliged to ensure a rigid limitation of exchange rate fluctuations.

The use of foreign exchange restrictions is associated, at least, with a number of reasons: first, restrictions are used to strengthen the regulatory impact on the balance of payments; secondly, to solve problems of repayment of debts on foreign loans; thirdly, many states seek to concentrate foreign currency in their hands in order to spend it more effectively on economic development; fourth, in order to increase their foreign exchange reserves, they introduce such official rates, which market events cannot be sustained with limited reserves, because these rates differ significantly from potential market ones; fifth, in relatively poor countries, governments simply cannot allow free sale (and hence import and export) of the national currency since the latter is a debt obligation of the country, the possession of which allows at any time show it for payment (Krokhina, 2015).

Thus, by combining the theoretical bases of the introduction of a floating exchange rate and the transition to inflation targeting with the practice of other countries and the economic characteristics of Ukraine, one can conclude that there is a need to introduce a transitional period, during which it is worthwhile to ensure:

1) increasing the efficiency of monetary policy operations and increasing the share of refinancing operations and securities operations in the open market in the NBU emission policy; 
2) the gradual liberalization of the capital market and the development of the banking system, as the abandonment of currency restrictions requires a certain redevelopment of the financial services market regulation system;

3) maintaining a sufficient level of gross international reserves. By the end of March 2013, the volume of gold and foreign exchange reserves amounted to 24728.61 million USD. According to the expanded criteria for adequacy of risk-based reserves (loss of access to the international capital market, national capital escape, and growth of current account deficit), this volume is insufficient;

4) maintenance of the exchange rate from significant nominal fluctuations within the specified limits, since the advantage of a floating regime is the very possibility of smoothing out the negative effects of the globalization process by adjusting the nominal exchange rate (Sorokivska, 2013).

Thus, a successful long-term foreign exchange policy should combine elements of flexibility and control, and its benchmark is to gradually shift to a floating exchange rate regime.

Consequently, currency restrictions in a number of cases are very closely related to credit and trade regulation. Their arsenal is varied; ineffective forms are replaced by more adapted to the peculiarities of the monetary and economic situation of the country and competition in the world market.

Aparticularattention should be paid to the comparative survey of foreign legislation on the legal status of digital money and state regulation of cryptocurrency business.

Canada. In June 2014, the Governor General of Canada approved a bill (Transactions Involving Bitcoins) according to which: Cryptocurrency exchanges are subject to registration at the Financial Transactions and Reports Analysis Centre of Canada (FINTRAC) (Financial Transactions and Reports Analysis Centre of Canada) as financial institutions; Companies should ensure compliance with anti-money laundering legislation: to notify the regulator of suspicious transactions, to introduce user verification, and more; Banks cannot open accounts for cryptocurrency exchanges that are not registered in FINTRAC. The bill extends both to companies incorporated in Canada and companies that provide relevant services in Canada but are registered in another jurisdiction. Payment for goods or services using cryptographic goods is taxable as a barter transaction. In the case of sale of a digital currency, a tax on profit or a capital gains tax is imposed. Cryptocurrency, obtained as a result of mining, carried out for commercial purposes, is subject to tax on income.

The USA. The state of California, the first of all US states that allowed the use of crypto foreign currency at the legislative level. The law (Assembly Bill No. 129) allows any corporation, association, or private person in California to engage in a turnover other than legitimate
US funds, and it came into force in early 2015. However, the management of the cryptocurrency business in the state is not regulated. In the state of New York, such a business was regulated in August 2015, when BitLicense - a license to run a cryptocurrency business was introduced by the New York State Financial Services Department (The United States is Falling Behind in Bitcoin Regulation. Kyle Torpey).

In the state of Washington, the digital currency is the object of money transfers (Money Transmission) in the sense of the Law "On Unification of Financial Services". This means that companies can execute crypto-currency transfers to a Washington resident only after receiving the Washington money transfer operator license (Washington Money Transmitter License). This requirement also applies to exchanges that provide currency exchange services for cryptocurrency and vice versa. Subject to this regulation are companies that provide cryptocurrency wallets to users and perform transactions for the exchange or transfer of digital currency. Companies that provide cryptographic currency wallets should conduct a security audit of the computer system in order to obtain the appropriate license (Uniform Money Services Act).

Japan. In May 2016, the Japanese parliament passed a law, according to which: Cryptocurrency operators are subject to registration at the Financial Services Agency; The Agency has the authority to carry out stock market inspections and, if necessary, may apply administrative measures; Cryptocurrency is recognized as a value similar to assets. In this case, the digital currency is not considered a legal tender, but as a means of exchange, through which you can buy goods, services or legal means of payment. Taxation of cryptocurrency and operations with it in Japan are carried out according to the standard rules defined in the tax legislation. Thus, the income received by an individual as a cryptocurrency is subject to income tax (Income Tax), the income of a legal entity in a digital currency - corporate tax (Corporate Tax). The sale of cryptocurrencies is subject to a Japanese analogue of value added tax (Japan Makes First Bitcoin-Related Drug Arrest).

For today, no one of the regulators (authorities) of the European Union adopted special rules for the regulation of cryptocurrency activities. However, Member Countries carry out legal regulation of exchange business, in particular, cryptocurrency. Some member states have legislative rules on the regulation of cryptocurrency business, whereas other countries do not conduct legal regulation of this business at all. In many of them, cryptocurrency business is regulated through reports, warnings, press releases, information notes issued by central banks or other regulatory bodies that do not have a mandatory order. In EU legislation, the legal regulation of cryptocurrency transactions is considered within the framework of the implementation of the policy of combating money 
laundering and terrorist financing (Directive (EU) 2015/849; A comparative review of foreign legislation on the legal status of digital money and state regulation of cryptocurrency business).

Analysing this problem, it is necessary to separate the draft Law of Ukraine "On Currency". The draft Law "On Currency" was developed in connection with the necessity of legislative consolidation of principles of transparent foreign exchange policy of Ukraine, regulation of the currency market, the need to restore the stability of the currency of Ukraine, and create a favourable investment climate in the country.

The current regime of currency regulation, which was established with the adoption of the Decree of the Cabinet of Ministers of Ukraine "On System of Currency Regulation and Currency Control" (Vidomosti of the Verkhovna Rada of Ukraine (VVR), 1993, No. 17, p. 184) and regulatory acts adopted in accordance with this Decree, is obsolete and does not correspond to the modern European practice of the organization of currency regulation. The system of currency regulation is non-transparent for subjects of currency transactions and creates additional difficulties when entering into currency legal relations. Moreover, the system of currency regulation and control is so inconsistent with time and demands of subjects of currency relations that cannot be changed by separate specifications/changes in the legislation and require a radical revision with the introduction of a new regime of currency regulation, which would correspond to the best practices of the European Union for the introduction of a free movement of capital.

The purpose of the bill is to establish a regime of currency regulation, which provides for the free exercise of currency transactions by their entities, aimed at improving the simplicity of such transactions, improving the investment climate and investment attractiveness of Ukraine, as well as the implementation of commitments undertaken by Ukraine under the Association Agreement between the European Union and the European Atomic Energy Community and their member states, of the one part, and Ukraine, of the other part, in particular, the introduction of regulatory principles of the movement of capital of the European Union (according to the Directive of the EEC Council of 24.06.1988 № 88/361/EEC) (Explanatory Note to draft Law of Ukraine "On Currency").
Adoption of the proposed draft Law of Ukraine will enable:

- to improve the legislative framework and bring it in line with the best European practices on the free movement of capital, which will expand the opportunities for residents to develop foreign economic activity and increase exports, contributing to the strengthening and development of the national economy;

- to create favourable conditions for investing capital in the Ukrainian economy, developing international relations, removing tensions in relations with foreign partners, and it will also have a beneficial effect on the business activity of foreign business entities/individuals in Ukraine;

- to improve the legislative provision of the implementation of a single state monetary policy, as well as the stability of the currency of Ukraine and the currency market of Ukraine, as factors of progressive development of the national economy and international economic cooperation.

As a result of the efforts taken by the states over the past two decades, in almost all countries with a market economy, the state's participation in increasing the competitiveness of domestic enterprises, in the development and cheapening of the necessary infrastructure for it has increased dramatically; the tax system, which encourages competitive enterprises, significantly rebuilds; rational investment, monetary and financial, and regional policies as the basis of currency regulation and currency control develop (Krokhina, 2015).

\section{Conclusion}

Summarizing the above, it should be noted that in the face of the overcoming negative effects of the financial and economic crisis, there is a need to solve the problems of the search for and implementation of such mechanisms of currency regulation and currency control, which would be most adequate to the current stage of development of the Ukrainian economy. However, Ukraine has no sufficient regulatory framework to counteract this phenomenon, dangerous for the state. A leading role in solving this issue is played by effective, impartial, and timely state financial monitoring, the system of which should be built on the basis of world experience.

\section{References:}

Savka O.I., Miedieliaieva O.S. Suchasni problemy valiutnoho rehuliuvannia v Ukraini [Modern issues of currency regulation in Ukraine] URL: http://www.rusnauka.com/16_ADEN_2010/Economics/68118.doc.htm

Sorokivska Z. (2013). Zarubizhnyi dosvid realizatsii valiutnoi polityky $\mathrm{v}$ konteksti zabezpechennia makroekonomichnoi stabilnosti [Foreign experience in the implementation of currency policy in the context of providing macroeconomic stability] Ukrainian Science: Past, Present, Future, Iss. 18, p. 144-153.

Motorniuk U.I., Kalynovska N.L. (2010). Problemy valiutnoho rehuliuvannia v Ukraini [Issues of currency regulation in Ukraine] Management and Entrepreneurship in Ukraine: Stages of Formation and Development Problems, №682.

Sevruk V.H., Pavlenko S.O. (2015). Zakhody protydii transnatsionalnomu narkobiznesu, shcho vchyniaietsia predstavnykamy okremykh etnichnykh hrup [Measures of counteraction to transnational drug trafficking 
committed by representatives of certain ethnic groups] Law Magazine of the National Academy of Internal Affairs, № 2, p. 193-205.

Yepifanova M.A. (2011). Systema valiutnoho rehuliuvannia v Ukraini v umovakh liberalizatsii finansovykh rynkiv [Currency regulation system in Ukraine in terms of liberalization of financial markets] [Text] : extended thesis abstract for Cand. Sc. (Economics) : 08.00.08 / Simon Kuznets Kharkiv National University of Economics, 20 p. Melykh O. (2012). Suchasni problemy valiutnoho rehuliuvannia v Ukraini [Modern issues of currency regulation in Ukraine] Urgent issues of international economic relations: financial strategies and institutional systems of international cooperation. Collection of papers of III Scientific Conference of Students and Young Scientists (8 November 2012). Ternopil: Publishing House "Vektor", p. 73-75.

Sevruk V.H. (2017). Protydiia Natsionalnoi politsii Ukrainy zlochynam, shcho vchyniaiutsia orhanizovanymy hrupamy ta zlochynnymy orhanizatsiiamy, yaki sformovani na etnichnii osnovi [Counteraction of the National Police of Ukraine to crimes that are committed by organized groups and criminal organizations formed on an ethnic basis] Entrepreneurship, Economy and Law, № 2 (252), p. 288-293.

Kamlyk M.I. (2005). Zabezpechennia zakonnosti u sferi pidpryiemnytstva: kryminolohichnyi aspekt [Law enforcement in the field of entrepreneurship: criminological aspect] Fight with Organized Crime and Corruption (Theory and Practice). Kyiv: Interdepartmental Scientific-Research Centre for Problems of Fighting Organized Crime, № 11, p. 91-99.

Platonova I.N. (1996). Pro valiutni obmezhennia dyv.: Valiutnyi rynok i valiutne rehuliuvannia: navch. posibnyk [On currency restrictions see.: Currency market and currency regulation: study]. M.: BEK, p. 69-84.

Krokhina Yu.A. (2015). Valiutne pravo: pidruchnyk dlia akademichnoho bakalavratu [Monetary law: textbook for academic Bachelor's programme] 5th edition, revised and enlarged. M.: Urait Publishing House, 553 p.

Pavlenko S.O. (2016). Shliakhy udoskonalennia pravovoho rehuliuvannia protydii osobam, vidnesenym do katehorii «zlodiiv u zakoniv» v Ukraini [Ways to improve legal regulation of counteraction to persons classified as "thieves in the laws" in Ukraine] Scientific Journal of Kherson State University, Iss. 6, vol. 3, p. 73-79.

Dzhavaha A.V. (2014). Zarubizhnyi dosvid pravovoho rehuliuvannia valiutnoho kontroliu [Foreign experience in the legal regulation of currency control] State and Regions. Series : Law, № 3, p. 28-33.

Yalta Interbank Conference: more questions than answers (2004). Herald of the National Bank of Ukraine, № 6, p. $12-13$.

Kizenkov D. (1997). Valyutnoe regulirovanie i kontrol [Currency regulation and control] Banking in Moscow, № 2, p. 22 .

Kolesnikov V.I., Shmyreva A.I., Klimov A.Yu. (1999). Problemyi valyutnogo regulirovaniya v stranah s ryinochnoy ekonomikoy [Issues of currency regulation in countries with a market economy] Novosibirsk, p. 26.

Platonova I.N. (1996). Valyutnyiy ryinok i valyutnoe regulirovanie [Currency market and currency regulation] Moscow, $450 \mathrm{p}$.

Khamaganova L.D. (2001). Mirovoy opyit v organizatsii valyutnogo regulirovaniya i valyutnogo kontrolya [Global experience in the organization of currency regulation and currency control] Irkutsk, $320 \mathrm{p}$.

Shmyreva A.I. (1999). Valyutnoe regulirovanie i kontrol v sisteme mezhdunarodnyih ekonomicheskih otnosheniy: monografiya [Currency regulation and control in the system of international economic relations : monograph] Saint Petersburg, 256 p.

Honcharuk I.V., Matsko O.M., Shparhalo H.Ye. (2010). Dosvid valiutno-kursovoho rehuliuvannia v transformatsiinykh ekonomikakh ' Experience of currency-rate regulation in transformational economies] Herald of Lviv Academy of Commerce, Iss. 33, p. 176-180.

Zhuravka F.O. (2008). Valiutna polityka v umovakh transformatsiinykh zmin ekonomiky: monografiya [Monetary policy in terms of transformational changes in the economy: monograph] Sumy: TOV “CPC «Dilovi Perspektyvy», SHEI «UAB of NBU», $336 \mathrm{p}$.

Transactions Involving Bitcoins. URL: http://www.canadiantaxlitigation.com/wp-content/uploads/2014/ 01/2013-0514701I7.txt?utm_source=Mondaq\&utm_medium=syndication\&utm_campaign=inter-article-link Financial Transactions and Reports Analysis Centre of Canada. URL: http://www. $\overline{f i n t r a c}$.gc.ca/intro-eng.asp Assembly Bill No. 129. URL: https://leginfo.legislature.ca.gov/faces/billNavClient.xhtml?bill_ $\mathrm{id}=201320140 \mathrm{AB} 129$

The United States is Falling Behind in Bitcoin Regulation. Kyle Torpey. Bitcoin Magazine. URL: https://bitcoinmagazine.com/articles/the-united-states-is-falling-behind-in-bitcoinregulation-1461604211/ Uniform Money Services Act. Interim Regulatory Guidance. Washington State Department of Financial Institutions. URL: http://www.dfi.wa.gov/documents/moneytransmitters/virtual-currency-interim-guidance.pdf

Japan Makes First Bitcoin-Related Drug Arrest. CoinDesk. URL: https://www.coindesk.com/japan-makes-firstbitcoin-related-drug-arrest/

Directive (EU) 2015/849 of the European Parliament and of the Council on 20 May 2015 on the prevention of the use of the financial system for the purposes of money laundering or terrorism financing and amending Regulation (EU) № 648/2012 of the European Parliament and of the Council. URL: http://www.sdfm.gov.ua/content/file/ Site_docs/2016/20160516/DIRECTIVE\%20(EU)\%202015_UA.htm

A comparative review of foreign legislation on the legal status of digital money and state regulation of cryptocurrency business. URL: http://radaprogram.org/sites/default/files/infocenter/piblications/22.pdf

Explanatory Note to draft Law of Ukraine “On Currency” (17.03.2018), p. 3. 